九州大学学術情報リポジトリ

Kyushu University Institutional Repository

\title{
Evaluation of Glued Laminated Timber Made from Low Grade Sugi Laminae
}

\section{Tanaka, Hiroshi}

Environment and Forestry Department, Miyazaki Prefectural Government

Morita, Hideki

Wood Processing Division, Miyazaki Prefectural Wood Utilization Research Center

Murase, Yasuhide

Laboratory of Wood Material Technology, Division of Biomaterial Science, Department of Forest and Forest Products Sciences, Faculty of Agriculture, Kyushu University

https://doi.org/10.5109/12863

出版情報: 九州大学大学院農学研究院紀要. 53 (2)，pp.491-495，2008-10-28. Faculty of Agriculture, Kyushu University

バージョン：

権利関係 : 


\title{
Evaluation of Glued Laminated Timber Made from Low Grade Sugi Laminae
}

\author{
Hiroshi TANAKA*1, Hideki MORITA*2 and Yasuhide MURASE*3 \\ Laboratory of Wood Material Technology, Division of Biomaterial Science, Department of Forest \\ and Forest Products Sciences, Faculty of Agriculture, Kyushu University, \\ Fukuoka 812-8581, Japanese \\ (Received June 27, 2008 and accepted July 16, 2008)
}

\begin{abstract}
This paper deals with strength properties of non-standard sugi (Cryptomeria japonica D. Don) glulam composed of core low-grade laminae, and face high-grade laminae. In-grade tests were conducted on non-standard glulams, as well as conventional sugi glulams of E65-F225 grade in Japanese Agricultural Standard (JAS). From the results of these tests, non-standard glulams were approximately equal to JAS type glulams both in bending strength and stiffness, which reflect the effectiveness of using high-grade lumber for face laminae. The lower fifth percentile tension strength for non-standard glulams were less than the published standard strength (SS) of E65-F225 grade, though none of the individual strength value less than the SS value. Compression strength for non-standard glulams were lower than for JAS type glulams, however the lower fifth percentile compression strength for non-standard glulams exceeded the SS value of E65-F225 grade extremely.
\end{abstract}

\section{INTRODUCTION}

Forests cover 588 thousand hectares or $76 \%$ of the total area of Miyazaki prefecture. The volume of timber produced in 2007 was 1.43 million $\mathrm{m}^{3}$, Miyazaki has consistently lead the nation in sugi (Cryptomeria japonica D. Don) output since 1991. However the quantity of annual average growth of sugi plantation forests reaches about 3 million $\mathrm{m}^{3}$, new application of the resource have to be developed. Japan's self-sufficiency rate of wood supply (industrial wood) was only 20\% in 2006 (Forest Agency, 2008). It is increasingly necessary to promote the use of wood, especially domestic wood with the increase in forests ready for harvest, and the interest to use of wood as global warming countermeasures. For the promotion of domestic wood consumption, the structure of wood produce industry should be converted for the efficient production of products which can meet market demands, including glued laminated timber (glulam), and the stable supply of products with clearly-stated quality and performance with low prices.

Glulam has developed for the structural members to construct the large-scale building such as dome or the gymnasium. Thus Japanese Agricultural Standard (JAS) for Structural Glulam (Ministry of Agriculture, Forestry and Fisheries, 1996) aimed to create wood products which are superior in strength characteristics to solid sawn lumber, and low-grade sugi which has higher growth rate and low modulus of elasticity (MOE) is confined to use as raw materials of the structural glulam

${ }^{1}$ Environment and Forestry Department, Miyazaki Prefectural Government, Japanese

Wood Processing Division, Miyazaki Prefectural Wood Utilization Research Center, Japanese

Laboratory of Wood Material Technology, Department of Forest and Forest Products Sciences, Faculty of Agriculture, Graduate Schools of Kyushu University, Japanese

* Corresponding author (E-mail: tanaka-hiroshi@pref.miyazaki. lg.jp)
(Kamiya, 2005). Therefore, the yield rate from logs is considerably low, and cutting the costs of production is difficult, when the structural glulam is going to be manufactured with sugi laminae. On the other hand, glulam circulating in the market are mainly used for structural members of wooden house recently. It's considered that the structural glulam with low-grade sugi laminae can be designed to meet application-specific performance requirements. In a typical glulam beam, stresses are highest near the top and bottom of the member, so the highest grades of laminae are placed near the surfaces, with lower grades of laminae placed in the core. This lay-up concept makes very efficient use of the lumber resource.

The purpose of this study was to investigate the strength properties of non-standard sugi glulam composed of core low-grade (non-standard grade) laminae and face high-grade laminae identified by JAS as L90 grade. The properties involved were bending, tension and compression parallel to the grain. In-grade tests were conducted on 5-ply and 7-ply non-standard glulams, as well as conventional sugi glulams of E65-F225 grade identified by JAS.

\section{MATERIALS AND METHODS}

\section{Test Materials}

The material used in this study was sugi grown in Miyazaki prefecture. Lumbers for laminating were kilndried to approximately $12 \%$ moisture content (MC). Following machine stress rating was conducted for the material to obtain the MOE of each laminae. Heterogeneously graded combination glulams were fabricated in a commercial operation at a representative sugi glulam plant in Miyazaki prefecture. In addition, all laminaes composing glulam contained no end joint. Adhesive which was applied to glulam manufacture in accordance with regulations and standards was aqueous vinyl polymer solution-isosianate. 
Type of glulam specimens and cross-sectional composition of laminae were shown in Figure 1. The study distinguished differences in laminae combination applied to glulam manufacture, JAS type and non-standard type. Within each type, glulam of two different depths were planned. The shallower glulams consisted of five laminae and were $150 \mathrm{~mm}$ deep, the deeper glulams contained seven laminae and were $210 \mathrm{~mm}$ deep. The compositions of JAS type glulams were face laminae as L80 grade $\left(7.85 \mathrm{kN} / \mathrm{mm}^{2}<\mathrm{MOE}<8.83 \mathrm{kN} / \mathrm{mm}^{2}\right)$, secondary outer layer laminae as L60 grade $\left(5.89 \mathrm{kN} / \mathrm{mm}^{2}<\mathrm{MOE}<\right.$ $\left.6.87 \mathrm{kN} / \mathrm{mm}^{2}\right)$, and core laminae as L50 grade $(4.91 \mathrm{kN} /$ $\mathrm{mm}^{2}<\mathrm{MOE}<5.89 \mathrm{kN} / \mathrm{mm}^{2}$ ) in accordance with JAS. The compositions of non-standard type glulams were face laminae identified by JAS as L90 grade $\left(8.83 \mathrm{kN} / \mathrm{mm}^{2}<\right.$ MOE $\left.<9.82 \mathrm{kN} / \mathrm{mm}^{2}\right)$ and core low-grade laminae $(\mathrm{N}-5$ group : $2.94 \mathrm{kN} / \mathrm{mm}^{2}<\mathrm{MOE}<3.92 \mathrm{kN} / \mathrm{mm}^{2}, \mathrm{~N}-7$ group : $3.92 \mathrm{kN} / \mathrm{mm}^{2}<\mathrm{MOE}<4.91 \mathrm{kN} / \mathrm{mm}^{2}$ ).

Specimen size of 5-ply and 7-ply manufactured glulams were dimensions of $105 \mathrm{~mm} \times 150 \mathrm{~mm} \times 3600 \mathrm{~mm}$ long and dimensions of $105 \mathrm{~mm} \times 210 \mathrm{~mm} \times 4000 \mathrm{~mm}$ long, respectively. For each group, twelve glulams were manufactured then transported to Miyazaki Prefectural Wood Utilization Research Center. Before the tests to destruction, each glulam was tested with a FFT-analyzer to obtain the dynamic $\mathrm{MOE}\left(\mathrm{E}_{\mathrm{d}}\right)$ in longitudinal vibration, and numbered. For each group, the odd numbered glulams were used for bending test specimens, and the even numbered glulams were cut off by two pieces, each

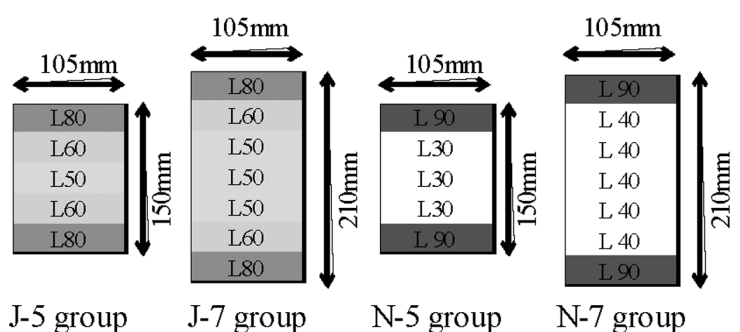

JAS type glulam (E65-F225) non-standard glulam piece was used for tension test specimens and compression test specimens. After the tests to destruction were completed, the MC and density of each glulam were determined. The matrix of the glulam specimens evaluated in the test program is shown in Table 1.

\section{Full-size testing and evaluation of the character- istic values}

Following the JAS procedures, full-size bending tests were conducted on four groups of glulam to establish the static MOE of glulam $\left(E_{b}\right)$ and bending strength $\left(f_{b}\right)$ for each specimen. Sample size of six was used for each group. The specimen lengths of 5-ply and 7-ply glulams were $3600 \mathrm{~mm}$ and $4000 \mathrm{~mm}$, respectively. The test configuration is shown in Figure 2 (simple supports, uniform loading, span-to-depth ratio of 18 to 1 and load spanto-depth ratio of 4 to 1 ). The loading speed did not exceed $14.7 \mathrm{~N} / \mathrm{mm}^{2} / \mathrm{min}$. No lateral bracing was used. Measurement of the $\mathrm{E}_{\mathrm{b}}$ was undertaken by measurement of center point deflection of the centerline of the beam relative to the position of the centerline at the ends of the beam. To evaluate the $\mathrm{E}_{\mathrm{b}}$, the incremental deflection for an incremental load was selected from the linear elastic, part of the load deflection graph.

Following the JAS procedures, full-size tension strength tests were conducted on four groups of glulam to establish the MOE in tension $\left(\mathrm{E}_{\mathrm{t}}\right)$ and tension strength parallel to the grain $\left(f_{t}\right)$ for each specimens. Sample size of six was used for each group. The test configuration is shown in Figure 3. Approximately $600 \mathrm{~mm}$ of length at each end of each specimen was held within the grips, leaving a test length of $1200 \mathrm{~mm}$. The rate of loading was one that leads to failure at about one minute. To evaluate the $\mathrm{E}_{\mathrm{t}}$, deformation per gauge length of $500 \mathrm{~mm}$ were recorded on ether side of the specimen.

Full-size compression strength tests were conducted on four groups of glulam in accordance with Testing Methods for Structural Timber Strength (Japan Housing and Wood Technology Center, 2000) to establish compression strength parallel to the grain $\left(\mathrm{f}_{\mathrm{c}}\right)$ for each specimens. Sample size of six was used for each group. The length of the specimens was $630 \mathrm{~mm}$. The test configuration is shown in Figure 4. The rate of loading was one that leads to failure at about one minute. No lateral bracing was used. Deformation measurements were not recorded for determination of compressive MOE.

Fig. 1. Cross-sectional compositions of glulams.

Table 1. Matrix of glulam specimens

\begin{tabular}{|c|c|c|c|c|c|c|c|}
\hline \multirow{2}{*}{ group } & \multirow{2}{*}{$n$} & \multicolumn{2}{|c|}{ Density } & \multicolumn{2}{|c|}{$M C$} & \multicolumn{2}{|c|}{$E_{\mathrm{d}}$} \\
\hline & & $A V\left(\mathrm{~kg} / \mathrm{m}^{3}\right)$ & $C V(\%)$ & $A V(\%)$ & $C V(\%)$ & $A V\left(\mathrm{kN} / \mathrm{m}^{2}\right)$ & $C V(\%)$ \\
\hline $\mathrm{J}-5$ & 12 & 411 & 2.60 & 11.8 & 3.62 & 7.19 & 2.09 \\
\hline $\mathrm{J}-7$ & 12 & 417 & 4.12 & 12.4 & 3.37 & 6.97 & 1.90 \\
\hline $\mathrm{N}-5$ & 12 & 405 & 3.96 & 12.7 & 4.68 & 6.18 & 3.95 \\
\hline $\mathrm{N}-7$ & 12 & 401 & 2.30 & 12.0 & 3.94 & 6.29 & 2.61 \\
\hline
\end{tabular}

Notes: $\mathrm{n}$ : Number of specimens, MC: Moisture content at test, $\mathrm{E}_{\mathrm{d}}$ : Dynamic modulus of elasticity, AV: Average value, CV: Coefficient of variation. 


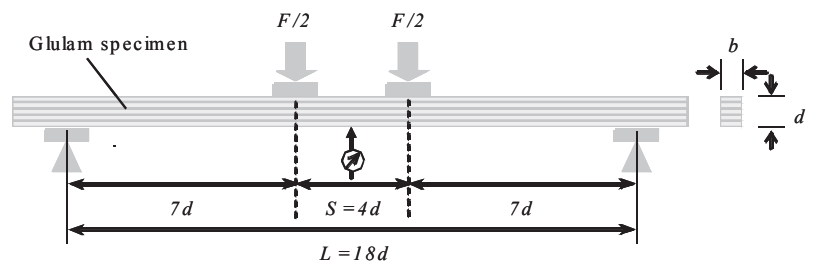

Fig. 2. Configulation for measurement of bending strength and stiffness.

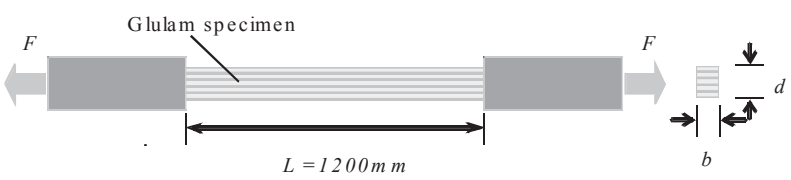

Fig. 3. Configulation for measurement of tension strength and stiffness parallel to the grain.

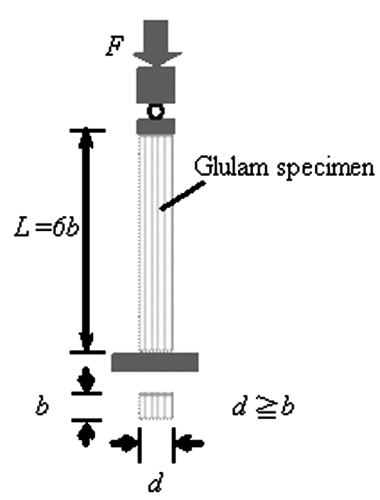

Fig. 4. Configulation for measurement of compression strength parallel to the grain.

\section{RESULTS AND DISCUSSION}

\section{Bending strength and stiffness}

The average air-dried density, $\mathrm{MC}$ and $\mathrm{E}_{\mathrm{d}}$ values for each group are shown in Table 1 . The average density and MC of all specimens were $409 \mathrm{~kg} / \mathrm{m}^{3}$ and $12.2 \%$, respectively. There was no significant difference in MC between JAS type and non-standard glulams. On the other hand, the average air-dried density for non-standard glulams were about 3\% lower than for JAS type glulams, and non-standard glulams had lower average $\mathrm{E}_{\mathrm{d}}$ values than JAS type glulams. It seems that the low grade laminae composing non-standard glulam had not only lower $M O E$ value but also lower density.

The average $\mathrm{E}_{\mathrm{b}}$ values for each group are shown in Table 2. The average $\mathrm{E}_{\mathrm{b}}$ values for J-5 group and N-5 group were similar, and the same found for the J-7 group and $\mathrm{N}-7$ group. Table 2 shows the estimated $\mathrm{E}_{\mathrm{b}}$ values $\left(\mathrm{E}_{\mathrm{b}-\mathrm{est}}\right)$ for each group based on the MOE values of the laminating grades use. The ratios of actual average $\mathrm{E}_{\mathrm{b}}$ values at test to those predicted $\mathrm{E}_{\mathrm{b}-\mathrm{est}}$ values range from 0.962 to 0.969 , which reflects the accuracy of the estimation. The results indicate that the expected additional stiffness of non-standard glulams was attained in the $\mathrm{E}_{\mathrm{b}}$ values, thus high $\mathrm{E}_{\mathrm{b}}$ glulam can be constructed using core low grade laminae and face high grade laminae.

The average and the lower fifth percentile exclusion limit (PTL) of fb for each group are shown in Table 2 and which are compared with the standard strength (SS) for structural glulam of E65-F225 grade published in Japan prior to June 2001 (Ministry of Land, Infrastructure, Transport and Tourism, 2001). The ratios of the average $\mathrm{f}_{\mathrm{b}}$ values for J-5 group to N-5 group and J-7 group to N-7 group were 0.879 and 1.07, respectively, no specific increase or decrease trend of the $f_{b}$ values could be established by examine the data. Then none of the individual $\mathrm{f}_{\mathrm{b}}$ values for each group were less than the SS value. In comparison with JAS type glulams, non-standard glulams performed well though the PTL value for N-7 group was slightly less than the SS value for E65-F225 grade. The results suggest the effectiveness of using material with greater MOE for face laminae, and the lamination of non-standard glulam has probability to provide improved utilization of low-grade sugi laminae.

Typical stress-deflection curves are shown in Figure 5. It has been observed that bending strength of glulam is generally governed by the strength of the tension face laminae. Therefore the mode of failure referred to failure of the tension face laminae, apparently. However the stress-deflection graph indicates that ductile fracture was observed in case of the bending tests for nonstandard glulams. It's considered that the initial catastrophic failures appeared to be compression failures in case of the non-standard glulams, because the face L90 grade laminae of non-standard glulam, which characterized by relatively few medium-to-large size knots and by straight grain, has higher tension strength compared with their compression strength.

Table 2. Results of bending tests

\begin{tabular}{|c|c|c|c|c|c|c|c|c|}
\hline \multirow{2}{*}{ groups } & \multirow{2}{*}{$n$} & \multicolumn{2}{|c|}{$E_{\mathrm{b}}$} & \multirow{2}{*}{$\begin{array}{c}E_{\mathrm{b}-\text { est }} \\
\left(\mathrm{kN} / \mathrm{mm}^{2}\right)\end{array}$} & \multicolumn{3}{|c|}{$f_{\mathrm{b}}$} & \multirow{2}{*}{$\begin{array}{c}S S \\
\left(\mathrm{~N} / \mathrm{mm}^{2}\right)\end{array}$} \\
\hline & & $A V\left(\mathrm{kN} / \mathrm{mm}^{3}\right)$ & $C V(\%)$ & & $A V\left(\mathrm{~N} / \mathrm{mm}^{2}\right)$ & $C V(\%)$ & $P T L\left(\mathrm{~N} / \mathrm{mm}^{2}\right)$ & \\
\hline $\mathrm{J}-5$ & 6 & 7.15 & 2.50 & 7.41 & 37.6 & 15.52 & 24.0 & 22.2 \\
\hline $\mathrm{J}-7$ & 6 & 6.83 & 2.79 & 7.05 & 36.4 & 10.15 & 27.7 & 22.2 \\
\hline $\mathrm{N}-5$ & 6 & 7.27 & 3.37 & 7.56 & 42.8 & 10.84 & 32.0 & - \\
\hline $\mathrm{N}-7$ & 6 & 6.77 & 2.38 & 7.04 & 34.1 & 15.36 & 21.9 & - \\
\hline
\end{tabular}

Notes: $\mathrm{E}_{\mathrm{b}}$ : Modulus of elasticity in bending, $\mathrm{E}_{\mathrm{b}-\mathrm{est}}$ : Estimated $\mathrm{E}_{\mathrm{b}}, \mathrm{f}_{\mathrm{b}}$ : Bending strength, SS: The published standard strength in the current Japanese building code, PTL: Lower $5 \%$ exclusion limit for a normal distribution, n, AV and CV: See Table 1. 

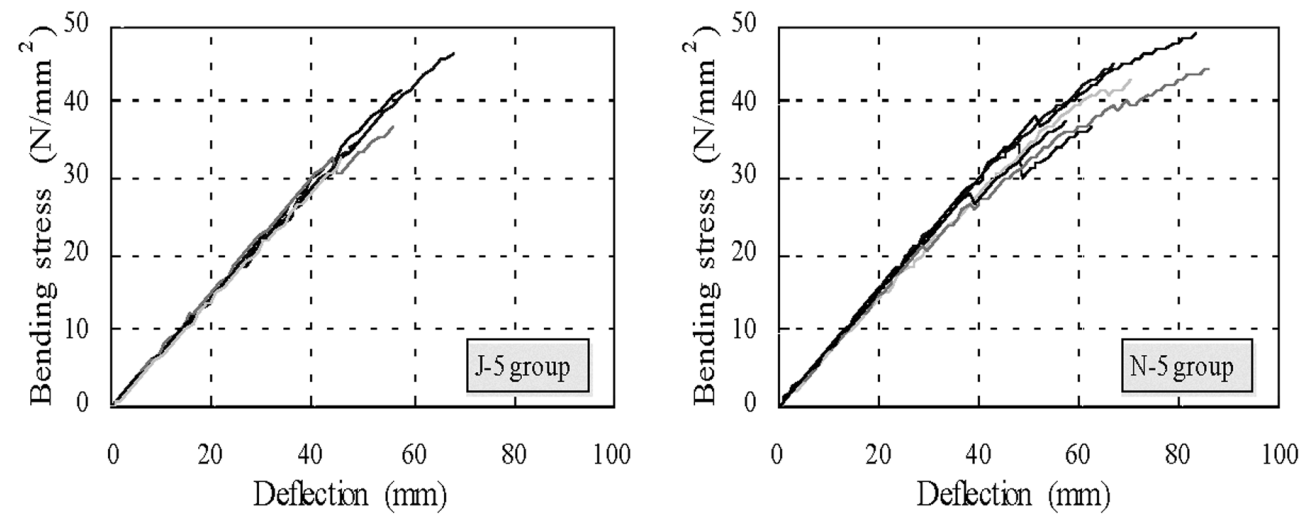

Fig. 5. Typical stress-deflection diagrams of bending tests for glulams.

\section{Tension strength and stiffness parallel to the grain}

The average $\mathrm{E}_{\mathrm{t}}$ values and the estimated $E_{\mathrm{t}}$ values $\left(\mathrm{E}_{\mathrm{t}-\mathrm{est}}\right)$, which means the average values of the laminating grades, for each group are shown in Table 3. The $\mathrm{E}_{\mathrm{t}}$ results were similar to the $\mathrm{E}_{\mathrm{d}}$ results. The average $\mathrm{E}_{\mathrm{t}}$ values for non-standard glulams were 11\% lower than for JAS type glulams as well as the $\mathrm{E}_{\mathrm{t} \text {-est }}$ values for nonstandard glulams were $15 \%$ lower than for JAS type glulams. The ratios of actual average Et values to the $\mathrm{E}_{\mathrm{t} \text {-est }}$ values varied from 1.01 to 1.13 , indicating that the $\mathrm{E}_{\mathrm{t}}$ values are reasonably close to the $\mathrm{E}_{\mathrm{t}-\mathrm{est}}$ values.

The average and the PTL values of $\mathrm{f}_{\mathrm{t}}$ for each group are shown in Table 3 and which are compared with the SS value for E65-F225 grade. The ratios of the average $\mathrm{f}_{\mathrm{t}}$ values for $\mathrm{J}-5$ group to $\mathrm{N}-5$ group and $\mathrm{J}-7$ group to $\mathrm{N}-7$ group were 1.05 and 0.870 , respectively, no clear relationship was exhibited between JAS type and nonstandard glulams. Then none of the individual $f_{t}$ values for each group were less than the SS value. However the coefficient of variation (CV) of $f_{t}$ for $J-7$ group was unusually low, while the CV value for $\mathrm{N}-7$ group was considerably high. Accordingly, N-7 group had a relatively low PTL value for the average $\mathrm{f}_{\mathrm{t}}$ value, and neither PTL values for N-5 group and N-7 group were less than the SS value.

In tension strength tests, the large bearing deformation at loading and clamping grips were observed, though almost all the specimens had decisive fractures appeared to be visible knots and grain deviations at a point outside the region of grips. It's considered that several $\mathrm{f}_{\mathrm{t}}$ values obtained in this study would be a lower bound of the true tension strength because of the effect of the bearing deformation.

\section{Compression strength parallel to the grain}

The average and the PTL values of $f_{c}$ for each group are shown in Table 4 and which are compared with the SS value for E65-F225 grade. A difference in $f_{c}$ values

Table 3. Results of tension tests

\begin{tabular}{|c|c|c|c|c|c|c|c|c|}
\hline \multirow{2}{*}{ groups } & \multirow{2}{*}{$n$} & \multicolumn{2}{|c|}{$E_{\mathrm{t}}$} & \multirow{2}{*}{$\begin{array}{c}E_{\text {t-est }} \\
\left(\mathrm{kN} / \mathrm{mm}^{2}\right)\end{array}$} & \multicolumn{3}{|c|}{$f_{\mathrm{t}}$} & \multirow{2}{*}{$\begin{array}{c}S S \\
\left(\mathrm{~N} / \mathrm{mm}^{2}\right)\end{array}$} \\
\hline & & $A V\left(\mathrm{kN} / \mathrm{mm}^{2}\right)$ & $C V(\%)$ & & $A V\left(\mathrm{~N} / \mathrm{mm}^{2}\right)$ & $C V(\%)$ & $P T L\left(\mathrm{~N} / \mathrm{mm}^{2}\right)$ & \\
\hline J-5 & 6 & 6.74 & 4.22 & 6.47 & 22.1 & 14.4 & 14.7 & 14.4 \\
\hline $\mathrm{J}-7$ & 6 & 6.24 & 7.14 & 6.02 & 22.0 & 3.51 & 20.2 & 14.4 \\
\hline $\mathrm{N}-5$ & 6 & 5.37 & 3.50 & 5.30 & 21.2 & 14.6 & 13.9 & - \\
\hline $\mathrm{N}-7$ & 6 & 6.00 & 4.59 & 5.32 & 25.2 & 23.6 & 11.3 & - \\
\hline
\end{tabular}

Notes: $\mathrm{E}_{\mathrm{t}}$ : Modulus of elasticity in tension, $\mathrm{E}_{\mathrm{t}-\mathrm{est}}$ : Estimated $\mathrm{E}_{\mathrm{t}}, \mathrm{f}_{\mathrm{t}}$ : Tension strength, $\mathrm{n}, \mathrm{AV}$ and CV: See Table 1 , SS and PTL: See Table 2.

Table 4. Results of compression tests

\begin{tabular}{cccccc}
\hline \multirow{2}{*}{ groups } & $n$ & \multicolumn{5}{c}{$f_{\mathrm{c}}$} & $\begin{array}{c}S S \\
\left(\mathrm{~N} / \mathrm{mm}^{2}\right)\end{array}$ \\
\cline { 3 - 5 } & & $A V\left(\mathrm{~N} / \mathrm{mm}^{2}\right)$ & $C V(\%)$ & $P T L\left(\mathrm{~N} / \mathrm{mm}^{2}\right)$ & 16.8 \\
J-5 & 6 & 33.6 & 3.61 & 30.8 & 16.8 \\
$\mathrm{~J}-7$ & 6 & 33.3 & 4.13 & 30.1 & - \\
$\mathrm{N}-5$ & 6 & 29.2 & 3.91 & 26.5 & - \\
$\mathrm{N}-7$ & 6 & 30.6 & 2.17 & 29.1 & \\
\hline
\end{tabular}

Notes: $\mathrm{f}_{\mathrm{c}}$ : Compression strength, $\mathrm{n}, \mathrm{AV}$ and CV: See Table 1, SS and PTL: See Table 2. 
between JAS type and non-standard glulams was expected. The ratios of the average $\mathrm{f}_{\mathrm{c}}$ values for the $\mathrm{J}-5$ group to $\mathrm{N}-5$ group and $\mathrm{J}-7$ group to $\mathrm{N}-7$ group were 1.15 and 1.09 , respectively, the $f_{c}$ values for non-standard glulams were lower than JAS type glulams both in average and PTL values. It's considered that the $\mathrm{f}_{c}$ values of glulams would be similar to the mean strength values of each laminae composing glulams in the same way of the results for $\mathrm{E}_{\mathrm{d}}$ and $\mathrm{E}_{\mathrm{t}}$. However the $\mathrm{CV}$ values of $\mathrm{f}_{\mathrm{c}}$ were extremely low compared with the CV values of $f_{b}$ and $f_{t}$. Therefore the PTL values for each group exceeded the SS value for E65-F225 grade, even a poor PTL value for N-5 group was 57\% higher than the SS value. This supports the idea that the SS value for compression may give conservative strength values for the E65-F225 grade glulam manufactured in accordance with JAS.

\section{CONCLUSIONS}

Strength properties of non-standard sugi glulam composed of core low-grade (non-standard grade) laminae and face laminae identified by JAS as L90 grade were investigated. The properties involved were bending, tension and compression parallel to the grain. In-grade tests were conducted on 5-ply and 7-ply nonstandard glulams, as well as conventional sugi glulams of E65-F225 grade identified by JAS. The results are summarized as follows:

1) Non-standard glulams were approximately equal to JAS type glulams both in bending strength and stiffness, which reflect the effectiveness of using material with greater $M O E$ for face laminae. The results suggest that the lamination of non-standard glulam has probability to provide improved utilization of low-grade sugi laminae. In addition, ductile fracture was observed in case of the bending tests for nonstandard glulams.

2) Tension stiffness for non-standard glulams was lower than for JAS type glulams. The lower fifth percentile tension strength for non-standard glulams were less than the published standard strength for E65-F225 grade in the current Japanese building code, though none of the individual strength value less than the standard strength. It's considered that tension strength obtained in this study would be a lower bound of the true tension strength because of the effect of the bearing deformation at loading and clamping grips.

3) Compression strength for non-standard glulams was lower than JAS type glulams both in average and lower fifth percentile values. However the coefficients of variation of compression strength were extremely low, therefore the lower fifth percentile compression strength for non-standard glulams considerably exceeded the standard strength for E65-F225 grade.

\section{REFERENCES}

Forestry Agency 2008 : Annual report on trends in forests and forestry. Japan

Ministry of Agriculture, Forestry and Fisheries 1996 : Japanese agricultural standard for structural glued laminated timber. Japan

Kamiya F 2005 : Jounal of timber engineering 63, pp. 17-20

Japan Housing and Wood Technology Center 2000 : Testing methods for structural timber strength. Tokyo, Japan

Ministry of Land, Infrastructure, Transport and Tourism 2001 . Notification no.1024. Tokyo, Japan 